\title{
NEWS OF THE PROFESSION
}

\section{STANISŁAW KOT, 1885-1975}

On December 26, 1975, Stanislaw Kot, one of the leading contemporary Polish historians, died in London at the age of ninety. Kot was of peasant stock, and his origins had an impact on the choice of subjects with which he dealt. His first lengthy book, which appeared in 1912, was devoted to Małopolska parish schools in the sixteenth to the eighteenth centuries, and in 1919 he published a masterly biography of Andrzej Frycz Modrzewski, a sixteenth-century religious and social reformer who passionately fought the social iniquities of the Polish penal code.

His range of interests was wide. In addition to education, where, among other studies, he published a general History of Education (1924 and, in an enlarged twovolume edition, 1933), he was interested in the history of political ideas and ventured into literary history: his new reading of Skarga's Parliamentary Sermons created quite a stir when it was first published in 1925 . He also wrote a short but meaty book on Western opinions of the Polish Commonwealth, printed in 1919 and still not superseded. He will be best remembered, however, as a pioneer in the field of the history of Reformation in Poland. His book on the social and political ideas of Polish Antitrinitarians, published in 1932, was translated into English under a too comprehensive title Socinianism in Poland (Boston, 1957). From among his numerous papers in the field, unfortunately not yet collected in book form, one should mention at least two: La Réforme dans le Grand-Duché de Lithuanie, facteur d'occidentalisation culturelle (Brussels, 1952) and Szymon Budny, der grösste Häretiker Lituaniens in 16. Jahrhundert (Graz, 1956).

A man full of enterprise and with a rare knack for organization, he founded, in 1919, a series of popular critical editions of Polish and foreign classics, Biblioteka Narodowa, which he edited until the war and which, in Poland, has played a role similar to that of the Classiques Garnier in France. Continued after the war under the editorship of one of Kot's former students, the series now counts about four hundred volumes.

His career was checkered. Born in 1885 , he studied in Lvov and was prominent in political youth organizations. He was named professor of history at Cracow University in 1920, but as one of the leading opponents of the Pilsudski regime he was deprived of his chair in 1933. After the outbreak of the war in 1939, he managed to escape to the West, was a member of the Polish Government in Exile in Angers and in London, and for one year, 1941/42, was the Polish ambassador in Moscow. After the war he returned to Poland and became Polish ambassador in Rome, but in 1947, when Stanisław Mikolajczyk, the chairman of the Polish Peasant Party (of which Kot was one of the leaders), fled Poland, Kot resigned the ambassadorial post and emigrated to the West. After a stroke in 1964, which left him paralyzed, he spent the last twelve years of his life in a London hospital.

His scholarly achievements won him not only an early membership in the Polish Academy of Sciences, but also honorary degrees from Oxford and Basel Universities. 